\title{
PENGARUH PENGGUNAAN INFORMASI AKUNTANSI DAN MANAJEMEN MODAL KERJA PELAKU UMKM TERHADAP KEBERHASILAN USAHA DENGAN UMUR USAHASEBAGAI VARIABEL PEMODERASI (STUDI KASUS PADA INDUSTRI KREATIF DI YOGYAKARTA)
}

\author{
Khoirunnisa Cahya Firdarini*, Agung Slamet Prasetyo \\ STIE Widya Wiwaha Yogyakarta \\ firdanisa23319@gmail.com
}

\begin{abstract}
Small and medium enterprises (SMEs) are one of important sector of national economic that have contributed to labor absorption and Gross Domestic Product (GDP). They could survive of financial crisis both in national and global scale.

This research examines the effect of accounting information and working capital management toward business success of small and medium enterprise (SMEs) with age of business as moderating variable. The population of this research are small and medium enterprises (SMEs) in creative industries sector operated in Yogyakarta district. They are handycraft, culinary and fashion. Based on purposive sampling method, total sample of this research is 200 SMEs. Hypothesis testing used is path analysis using structural equation modelling (SEM). The test result shows that accounting information and working capital management have positive and significant effect to the success of SMEs.Age of business as moderating variable also have positive and significant effect to the success of SMEs.
\end{abstract}

Keywords: SMEs, accounting information, working capital management, business success, creative industries

\begin{abstract}
ABSTRAK
Usaha mikro, kecil dan menengah merupakan salah satu sektor penggerak perekonomian bangsa yang berkontribusi terhadap penyerapan tenaga kerja dan peningkatan Produk Domestik Bruto (PDB). UMKM juga terbukti mampu bertahan terhadap krisis ekonomi baik krisis ekonomi nasional maupun global. Penelitian ini berfokus pada UMKM yang bergerak di sektor industri kreatifdi Daerah Istimewa Yogyakarta. Industri kreatif sendiri meliputi usaha kerajinan, kuliner, dan fashion.

Tujuan penelitian ini adalah untuk menguji pengaruh penggunaan informasi akuntansi dan manajemen modal kerja para pelaku UMKM terhadap keberhasilan usaha dengan menggunakan umur usaha sebagai variabel moderasi. Berdasarkan metode purposive sampling, diperoleh total sampel 200 unit. Pengujian hipotesis dilakukan dengan menggunakan Stuctural Equation Modelling (SEM). Hasil pengujian hipotesis menunjukkan bahwa penggunaan informasi akuntansi dan manajemen modal kerja berpengaruh positif terhadap keberhasilan usaha. Umur usaha sebagai variabel pemoderasi juga terbukti berpengaruh terhadap keberhasilan UMKM.
\end{abstract}

Kata Kunci: UMKM; penggunaan informasi akuntansi; manajemen modal kerja; keberhasilan usaha; industri kreatif 


\section{PENDAHULUAN}

\section{1. Latar Belakang}

UMKMmerupakan sektor ekonomi yang berkembang dengan pesat dan menjadi tulang punggung perekonomian bangsa.Jenis usaha ini mampu mendongkrak laju perekonomian baik pada tingkat lokal maupun nasional, namun di samping kemajuan yang telah dicapai, mereka juga menghadapi tantangan dari sisi eksternal maupun internal. Dari sisi eksternal mereka dihadapkan pada pasar global dan fenomena pasar bebas dimana arus barang, jasa dan informasi mengalir sedemikian cepat sehingga persaingan usaha menjadi hal yang tak terhindarkan, seperti pemberlakuan ACFTA yang berlaku pada tahun 2010(Saefulah, 2016).

Dari sisi internal sebagian besar UMKM mengalami beberapa kendala diantaranya adalah pengelolaan penggunaan informasi akuntansi dan manajemen modal kerja (Arlianto, 2014). Mereka masih cenderung mengabaikan pentingnya penggunaan informasi akuntansi dan melakukan pembukuan pada saat kegiatan usaha baru memasuki tahapan awal pertumbuhan sehingga hal ini menjadi hambatan di dalam mengetahui kondisi keuangan, perencanaan keuangan dan upaya peminjaman dana yang pada akhirnya akan menghambat keberhasilan usaha.Pada umumnya kesadaran pelaku UMKM akan pentingnya penggunaan informasi akuntansi akan meningkat seiring dengan bertambahnya umur usaha.

Di samping penggunaan informasi akuntansi, modal kerja mutlak diperlukan oleh sebuah usaha untuk menunjang kegiatan operasional dan menjamin perputaran usaha. Dalam hal ini, manajemen modal kerja memainkan peranan penting untuk menjamin kegiatan operasional dapat berjalan dengan baik sekaligus dapat menangkap peluang investasi untuk meningkatkan profitabilitas. Efektivitas manajemen modal kerja akan semakin meningkat seiring dengan bertambahnya umur UMKM sehingga akan semakin memperbaiki proses penentuan kecukupan jumlah ketersediaan modal kerja yang diperlukan untuk mencapai keberhasilan usaha.

Penelitian ini menggunakan populasi UMKM yang bergerak di bidang industri kreatif di Daerah Istimewa Yogyakarta dengan pertimbangan bahwa Yogyakarta yang merupakan kota pelajar dan menjadi kota tujuan wisata budaya mampu membentuk iklim usaha baru yang memunculkan banyak komunitas bisnis yang sebagian besar bergerak di bidang industri kreatif. Industri kreatif sendiri dapat diartikan sebagai industri yang berasal dari pemanfaatan kreatifitas, keterampilan serta bakat individu untuk menciptakan lapangan pekerjaan melalui 
penciptaan daya kreasi dan daya cipta individu (Junaidi, 2017).

Berdasarkan studi pemetaan industri kreatif yang dilakukan oleh Departemen Perdagangan Republik Indonesia, subsektor industri kreatif antara lain periklanan, arsitektur, barang seni, kerajinan, desain, fashion, video, film dan fotografi, permainan interaktif, musik, seni pertunjukan, penerbitan dan percetakan, penerbitan buku, jurnal, koran, layanan komputer dan piranti lunak serta teknologi informasi. Penelitian ini berfokus pada tiga jenis industri kreatif yang terbesar di Yogyakarta menurut data Dinas Koperasi dan UMKM DIY tahun 2017 yaitu bidang kerajinan, kuliner, dan fashion.

\section{2. Rumusan Masalah}

Berdasarkan uraian latar belakang di atas, rumusan masalah penelitian ini adalah sebagai berikut:

1) Apakah penggunaan informasi akuntansi berpengaruh positif terhadap keberhasilan usaha?

2) Apakah manajemen modal kerja berpengaruh positif terhadap keberhasilan usaha?

3) Apakah umur usaha memoderasi pengaruh penggunaan informasi akuntansi terhadap keberhasilan usaha?

4) Apakah umur usaha memoderasi pengaruh manajemen modal kerja terhadap keberhasilan usaha?

\section{3. Tujuan Penelitian}

1) Menguji pengaruh penggunaan informasi akuntansi terhadap keberhasilan usaha

2) Menguji pengaruh umur usaha sebagai variabel pemoderasi pengaruh penggunaan informasi akuntansi terhadap keberhasilan usaha

3) Menguji pengaruh manajemen modal kerja terhadap keberhasilan usaha

4) Menguji pengaruh umur usaha sebagai variabel pemoderasi pengaruh manajemen modal kerja terhadap keberhasilan usaha

\section{TINJAUAN PUSTAKA}

\section{1. Landasan Teori}

\subsubsection{Capacity Building}

Capacity building adalah proses atau kegiatan memperbaiki kemampuan seseorang, kelompok, organisasi atau sistem untuk mencapai tujuan atau kinerja yang lebih baik (Brown et. al, 2011). Di dalam konteks bisnis, seorang individu atau pelaku usaha dituntut untuk terus meningkatkan keterampilan dan kemampuannya dengan melakukan perbaikan berkelanjutan baik di bidang keuangan maupun non keuangan.

\subsubsection{Trade off Theory}

Trade off theory merupakan suatu teori untuk menentukan besarnya modal optimal untuk meningkatkan nilai perusahaan. Dalam penentuan kebijakan 
modal kerja yang efisien, pemilik usaha akan dihadapkan pada masalah adanya trade off antara faktor likuiditas dan profitabilitas. Jika pemilik memutuskan menetapkan modal kerja dalam jumlah yang besar, kemungkinan tingkat likuiditas akan terjaga namun kesempatan memaksimalkan laba akan menurun pada akhirnya berdampak pada profitabilitas. Sebaliknya jika perusahaan ingin memaksimalkan profitabilitas, kemungkinan akan mempengaruhi tingkat likuiditas perusahaan.

\section{2. Definisi Operasional Variabel}

\subsubsection{Definisi UMKM}

Menurut Undang-Undang No.20

Pasal 1 Tahun 2008 mengenaiUMKM, kriteria usaha kecil sesuai yang telah ditetapkan dalam undang-undang ini dengan kriteria sebagai berikut:

Tabel 1 Kriteria UMKM

\begin{tabular}{|l|l|l|l|}
\hline No & & \multicolumn{2}{|c|}{ Kriteria } \\
\hline & & Aset & Omset \\
\hline 1 & Usaha & Maksimal & Maksimal \\
& Mikro & 50 juta & 300 juta \\
\hline 2 & Usaha & $>50$ juta - & $>300$ juta \\
& Kecil & 500 juta & $-2,5 \mathrm{M}$ \\
\hline 3 & Usaha & $>500$ juta & $>2,5 \mathrm{M}-$ \\
& Menengah & $-10 \mathrm{M}$ & $50 \mathrm{M}$ \\
\hline
\end{tabular}

\subsubsection{Definisi Informasi Akuntansi}

Informasi akuntansi merupakan informasi kuantitatif tentang entitas ekonomi yang bermanfaat untuk pengambilan keputusan ekonomi dalam menentukan pilihan diantara alternatif tindakan(Belkaoui, 2010 dalam Sugianto,
2017). Menurutnya,informasi akuntansi dikelompokkan menjadi tiga jenis yaituinformasi operasi, informasi akuntansi manajemen dan informasi akuntansi keuangan.

\subsubsection{Definisi Modal Kerja}

Kasmir(2016) mendefinisikan modal kerja sebagai sejumlah dana yang digunakan untuk menutup kebutuhan operasional sehari-hari yang terdiri dari kas, surat-surat berharga, piutang dan persediaan serta utang lancar. Modal kerja yang cukup akan membantu proses perencanaan keuangan, memungkinkan pemilik usaha untuk melunasi kewajiban tepat pada waktunya dan menyesuaikan jumlah pesediaan yang harus tersedia

\subsubsection{Definisi Keberhasilan Usaha}

Keberhasilan usaha dapat diartikan sebagai persepsi pemilik tentang kinerja bisnisnya dibandingkan dengan tujuan yang ingin dicapai. Keberhasilan usaha dapat ditandai dengan peningkatan jumlah penjualan, meningkatnya jumlah produksi, meningkatnya keuntungan atau laba serta usaha yang selalu berkembang (Arlianto, 2014) sedangkan menurut Lindrayanti (2013) keberhasilan usaha ditandai dengan bertambahnya jumlah karyawan dan meningkatnya jumlah omset.

\section{3. Pembahasan Hasil Penelitian Sebelumnya}

Penelitian empiris sebelumnya mengenai faktor-faktor yang mempengaruhi keberhasilan usaha pernah 
dilakukan oleh beberapa peneliti diantaranya Indriani (2010), Nnena (2012), Arlianto (2014), Smirat (2013) dan Ermaliana (2013).Akan tetapi penelitian tersebut menunjukkan hasil yang berbedabeda.

Penelitian yang dilakukan oleh Indriani (2010) terhadap UMKM di Yogyakarta menunjukkan bahwa penggunaan informasi akuntansi mampu memperbaiki pengambilan keputusan oleh para penggunanya. Hasil penelitiannya menunjukkan adanya pengaruh yang positif dan signifikan antara penggunaan informasi akuntansi terhadap keberhasilan usaha. Hasil penelitiannya didukung oleh Nnena (2012) dan Arlianto (2014) yang menyatakan bahwa informasi akuntansi memegang kunci peranan yang penting bagi keberhasilan usaha kecil dan menengah dalam rangka pengambilan keputusan yang bersifat keuangan. Hasil yang serupa juga ditunjukkan oleh penelitian yang dilakukan oleh Smirat (2013) yang menyatakan bahwa praktik akuntansi yang baik berpengaruh positif terhadap keberhasilan UMKM. Penelitian ini mengambil sampel UMKM yang bergerak di sektor retail dan manufaktur di Yordania.Hasil yang berbeda ditunjukkan oleh penelitian yang dilakukan oleh Ermaliana (2013). Di dalam penelitiannya menunjukkan bahwa penggunaan informasi dalam pengelolaan UMKM tidak berpengaruh pada peningkatan kegiatan usaha.

Penelitian mengenai pengaruh modal kerjaterhadap keberhasilan usaha pernah dilakukan oleh Indriyatni (2013), Purwanti (2013)dan Hidayati dan Soesatyo (2016). Hasil penelitiannya menunjukkan bahwa modal kerjamemiliki pengaruh positif yang signifikan terhadap keberhasilan UMKM.

\section{4. Pengembangan Hipotesis}

\subsubsection{Pengaruh penggunaan informasi akuntansi terhadap keberhasilan usaha}

Kompleksitas kegiatan usaha semakin meningkat seiring dengan peningkatan skala usaha mereka. Hal ini akan berdampak pada peningkatan kebutuhan terhadap berbagai informasi baik informasi yang bersifat finansial maupun non-finansial. Untuk memenuhi tuntutan tersebut, para pelaku usaha dituntut untuk menggunakan informasi akuntansi secara baik sehingga dapat mendukung upaya mereka dalam mencapai keberhasilan. Di dalam penelitiannya, Arlianto (2014) menyebutkan bahwa informasi akuntansi yang digunakan oleh perusahaan dalam skala kecil dan menengah dapat mendukung keberhasilan usaha. Berdasarkan uraian tersebut, maka dapat dirumuskan hipotesis sebagai berikut: 
H1: Penggunaan informasi akuntansi berpengaruh positif terhadap keberhasilan usaha

\subsubsection{Pengaruh penggunaan informasi} akuntansi terhadap keberhasilan usaha dengan umur usaha sebagai variabel pemoderasi

Pada saat UMKM baru memasuki tahapan awal pendirian, biasanya pemilik cenderung kurang memperhatikan penggunaan informasi akuntansi dan melakukan pembukuan sehingga menghambatproses perencanaan keuangan dan upaya peminjaman dana yang pada akhirnya akan menghambat keberhasilan usaha. Akan tetapi dengan semakin meningkatnya umur dan skala usaha, akan semakin meningkat pula tingkat penjualan dan omsetnya sehingga kebutuhan terhadap informasi akuntansi sebagai bahan pengambilan keputusan akan bertambah untuk memenuhi peningkatan tersebut

H2: Umur usaha memoderasi pengaruh penggunaan informasi akuntansi terhadap keberhasilan usaha

\subsubsection{Pengaruh kecukupan modal kerja terhadap keberhasilan usaha}

Ketepatan penentuan jumlah modal kerja yang dibutuhkan oleh suatu usaha diperlukan untuk manjamin kelancaran kegiatan operasional. Kekurangan modal kerja akan menyebabkan terhambatnya proses produksi dan sebaliknya jumlah modal kerja yang berlebihan akan menghambat perusahaan untuk memperoleh peluang investasi karena modal kerja hanya berputar untuk kegiatan operasional usaha tersebut sehingga pemilik usaha perlu menentukan jumlah modal kerja yang tepat untuk menjamin kegiatan operasional berjalan dengan lancar dan dapat menangkap peluang investasi untuk meningkatkan profitabilitas sehingga dapat mencapai keberhasilan usaha.

H3: Manajemen modal kerja berpengaruh positif terhadap keberhasilan usaha

\subsubsection{Pengaruh kecukupan modal kerja terhadap keberhasilan usaha dengan umur usaha sebagai variabel pemoderasi}

Bosma et al. (2011) menyatakan bahwa UMKM yang baru mencapai tahap pertumbuhan awal (start up) harus melakukan perencanaan bisnis secara matang baik dalam hal keuangan maupun non keuangan. Usaha yang baru berdiri perlu menetapkan rencana jangka pendek, jangka menengah dan jangka panjang dengan menetapkan jumlah dana yang diperlukan untuk kegiatan operasional dan berinvestasi. Dalam hal ini, manajemen modal kerja memainkan peranan penting untuk menjamin kegiatan operasional dapat berjalan dengan baik. Seiring dengan bertambahnya umur UMKM akan semakin memperbaiki proses penentuan kecukupan jumlah ketersediaan modal kerja yang 
diperlukan untuk mencapai keberhasilan usaha.

H4: Umur usaha memoderasi pengaruh manajemen modal kerja terhadap keberhasilan usaha

\section{METODE}

\section{1. Jenis dan Sumber data}

Penelitian ini menggunakan data primer, yaitu data yang dikumpulkan sendiri oleh peneliti langsung dari sumber pertama atau tempat objek penelitian dilakukan (Rochmana, 2011). Pengumpulan data dilakukan dengan dua metode, yaitu dengan melakukan wawancara denganpelaku UMKM yang bergerak dalam industri kreatif dan memberikan kuesioner menggunakan skala likert kepada responden yaitu para pelaku UMKM.

\section{2. Populasi dan Sampel}

Populasi yang digunakan di dalam penelitian ini adalah perusahaan dalam kategori usaha mikro kecil dan menengah yang bergerak di industri kreatif yang berstatus aktif yang terdaftar di Dinas Perindustrian dan Perdagangan Daerah Istimewa Yogyakarta. Jumlah total populasi sebanyak di dalam penelitian ini adalah 230 unit. Teknik penentuan sampel yang digunakan adalah purposive sampling method yaitu memilih responden dengan menggunakan kriteria-kriteria yang telah ditetapkan.Total sampel yang diperoleh adalah sebesar 200 unit.

\section{3. Pengukuran Variabel Penelitian}

Penelitian ini menggunakan dua variabel independen yaitu penggunaan informasi akuntansi dan manajemen modal kerja serta satu variabel moderasi yaitu umur usaha dan satu variabel dependen yaitu keberhasilan usaha. Indikator masing-masing instrumen penelitian akan dijelaskan dalam tabel berikut:

1. Penggunaan Informasi Akuntansi (Arlianto, 2014 dan Rini, 2016)

a. Informasi Akuntansi digunakan untuk mengetahui jumlah produksi harian

b. Informasi Akuntansi digunakan untuk mengetahui jumlah Pembelian Bahan Baku

c. Informasi Akuntansi digunakan untuk mengetahui jumlah Pemakaian bahan baku

d. Informasi Akuntansi digunakan untuk mengetahui jumlah Penjualan Harian

e. Informasi Akuntansi digunakan untuk menentukan harga jual produk

f. Informasi Akuntansi digunakan untuk menghitung keuntungan dari penjualan produk

g. Informasi Akuntansi digunakan untuk penghitungan upah karyawan

2. Manajemen Modal Kerja (Indriyatni, 2013)

a. Kebutuhan bahan baku untuk satu kali proses produksi

b. Biaya operasional yang dikeluarkan 
c. Jumlah dana yang tersedia yang tidak untuk dikonsumsi

3. Keberhasilan Usaha (Rini 2016, Mahrouq 2010 danSmirat, 2013)

a. Adanya peningkatan penjualan tiap bulan

b. Adanya peningkatan omset tiap bulan

c. Adanya peningkatan modal usaha

d. Adanya peningkatan daerah pemasaran

e. Adanya peningkatan jumlah karyawan

f. Adanya peningkatan jumlah customer

\section{4. Metode Analisis}

Data dalam penelitian ini dianalisis dengan metode Stuctural Equation Modelling (SEM) menggunakan software AMOS v.23. Tahapan prosedur SEM dilakukan dengan tabulasi data hasil pengisian kuesioner, kemudian di analisis dengan metode SEM dengan tahapan spesifikasi model, identifikasi model, estimasi model, uji validitas dan reliabilitas, uji kecocokan model dan respesifikasi model.Masing-masing item indikator diukur dengan menggunakan skala semantik diferensial yang ditunjukkan oleh dua kutub, dimana kutub negatif diberi skor 1 dan kutub positif diberi skor 5. Skor masing-masing indikator menunjukkan total nilai dari item indikator.
Uji validitas digunakan untuk mengetahui apakah pertanyaan-pertanyaan yang diajukan di dalam kuesioner cukup representatif. Jika suatu variabel manifest atau indikator memiliki nilai t-value < 1,96, maka variabel manifest atau indikator tersebut tidak signifikan dan dapat dihapuskan dari model. Pengujian berikutnya adalah uji reliabilitas, yaitu sebuah pengujian yang digunakan untuk menunjukkan sejauh mana alat ukur dapat diandalkan atau dapat dipercaya. Uji reliabilitas dilakukan dengan menggunakan uji statistik cronbach's alpha $(\alpha)$ dengan ketentuan bahwa variabel yang diteliti dinyatakan reliabel apabila nilai cronbach's alpha $(\alpha)$ adalah di atas 0,6 (Ghozali, 2011).

Uji kecocokan keseluruhan model (measurement model) dilakukan untuk mengevaluasi secara umum derajat kecocokan (goodness of fit). Tahapan berikutnya adalah structural model untuk memperoleh sejumlah korelasi yang menunjukkan hubungan antar konstruk. Hasil kesesuaian uji kecocokan model dengan metode SEM dapat dilihat dari nilai indikator goodness of fit seperti yang dirangkum pada tabel berikut: 
Tabel 3 Indeks goodness of fit

\section{Goodness of fit index Cut-off value}

x,2(Chi-square) Diharapkan kecil

Significance Probability $\geq 0.05$

RMSEA

$\leq 0.08$

GFI

$\geq 0.90$

AGFI

$\geq 0.90$

CMIN/DF

$\leq 2.00$

TLI

$\geq 0.95$

CFI $\geq 0.95$

Berdasarkan hasil distribusi

kuesiner kepada para responden serta hasil wawancara yang telah dilakukan, diperoleh hasil sebagai berikut:

Tabel 4 Hasil Pemilihan Sampel

\begin{tabular}{|l|l|c|}
\hline No & \multicolumn{1}{|c|}{ Kriteria } & Jumlah \\
\hline 1 & $\begin{array}{l}\text { Perusahaan yang } \\
\text { tergolong dalam } \\
\text { kategori UMKM di } \\
\text { Yogyakarta }\end{array}$ & 230 \\
\hline 2 & $\begin{array}{l}\text { Data yang hilang/ tidak } \\
\text { diisi secara lengkap oleh } \\
\text { responden }\end{array}$ & 30 \\
\hline \multicolumn{1}{|c|}{ Total sampel } & $\mathbf{2 0 0}$ \\
\hline
\end{tabular}

Rincian distribusi kategori UMKM

bidang industri kreatif yang terpilih sebagai sampel penelitian menurut jenis usahanya disajikan dalam Tabel 3.4.Berdasarkan tabel tersebut dapat diketahui bahwa jenis usaha terbesar yang diambil sebagai sampel di dalam penelitian ini adalah industri kerajinan tangan yang meliputi industri pembuatan batik tulis, gerabah dan aneka souvenir sebanyak 88 UMKM (44\%) dari total populasi, diikuti oleh industri kuliner sebanyak 70 UMKM (35\%) dari total populasi dan industri fashion sebanyak 42 UMKM (21\%) dari total populasi seperti yang ditunjukkan pada tabel 3.4 berikut:

Tabel 5Distribusi Usaha Sampel Penelitian

\begin{tabular}{|c|c|}
\hline Jenis Usaha & Jumlah \\
\hline Kerajinan tangan & 88 \\
\hline Kuliner & 70 \\
\hline Fashion & 42 \\
\hline TOTAL & 200 \\
\hline
\end{tabular}

Grafik 1 Persentase Distribusi Usaha

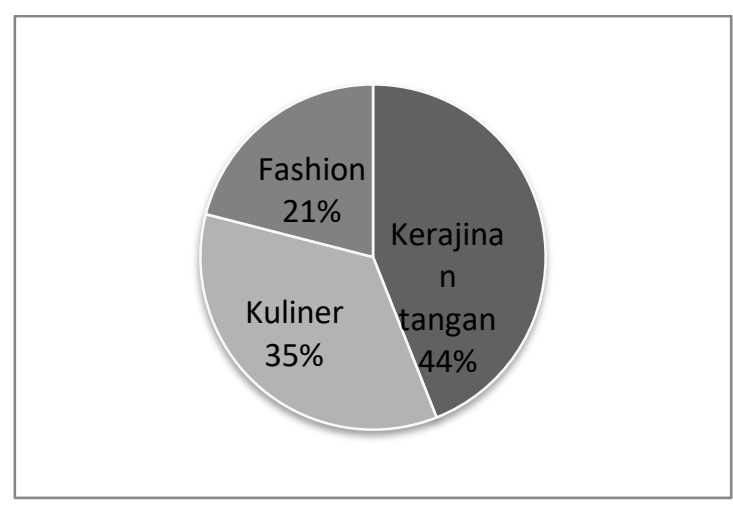

Sampel Penelitian

Berdasarkan proses pemilihan sampel yang telah dilakukan, diperoleh sebaran jumlah sampel penelitian berdasarkan umur usaha pada tabel 3.5 yang menunjukkan bahwa umur UMKM terbesar yang menjadi sampel di dalam penelitian ini berkisar antara 3 tahun sampai dengan 5 tahun sebanyak $37 \%$ diikuti dengan UMKM yang berumur 5 10 tahun sebanyak $32 \%$.

Tabel 6 Klasifikasi Sampel berdasarkan Umur Usaha

\begin{tabular}{|l|c|c|}
\hline Umur Usaha & Jumlah & Persentase \\
\hline$<1$ tahun & 21 & $11 \%$ \\
\hline 1-3 tahun & 35 & $18 \%$ \\
\hline $3-5$ tahun & 74 & $37 \%$ \\
\hline 5-10 tahun & 64 & $32 \%$ \\
\hline$>10$ tahun & 6 & $3 \%$ \\
\hline TOTAL & $\mathbf{2 0 0}$ & $\mathbf{1 0 0 \%}$ \\
\hline
\end{tabular}




\section{5. Model Penelitian}

Gambar 1 Model Penelitian

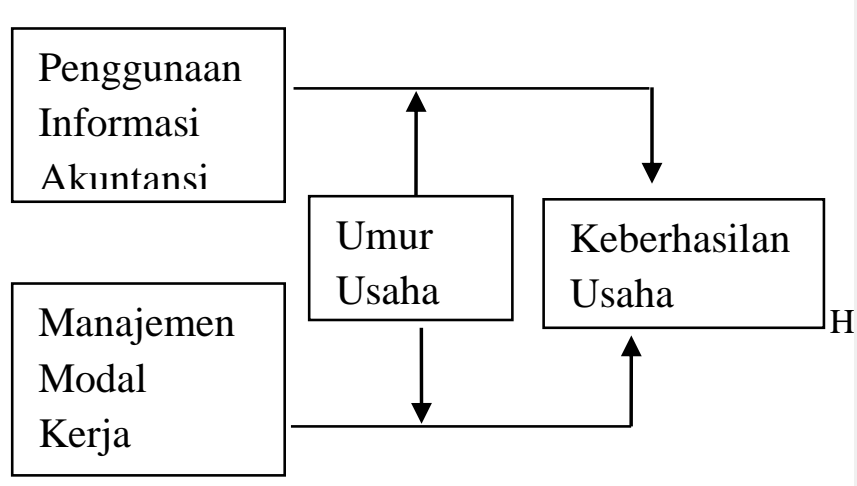

\section{PEMBAHASAN}

\section{1. Uji Validitas dan Reliabilitas}

Uji validitas dilakukan untuk mengetahui keandalan kuesioner pada setiap indikator atau item pertanyaan dengan menyebarkan kuesioner pendahuluan kepada 30 responden. Uji validitas dan reliabilitas dilakukan dengan menggunakan conformatory factor analysis pada masing-masing variabel laten yaitu penggunaan informasi akuntansi, manajemen modal kerja dan keberhasilan usaha dengan menggunakan program AMOS v.23. Hasil penelitian menunjukkan bahwa penggunaan informasi akuntansi, manajemen modal kerja dan keberhasilan usaha merupakan variable laten yang valid dan reliable.

\section{2. Pengujian Model Struktural}

Model struktural pada penelitian ini dijelaskan pada Gambar 4.1 sedangkan hasil pengujian keseluruhan model (overall model fit) dapat dilihat pada Tabel 4.1

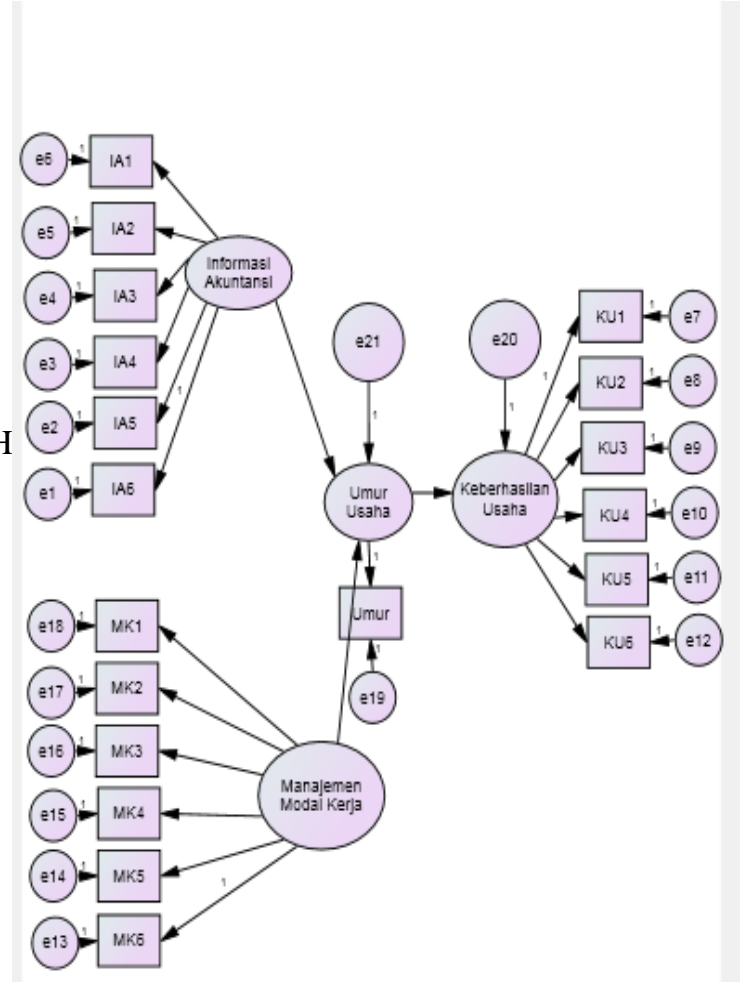

Gambar 2Modelstruktural dengan menggunakan AMOS v.23

Tabel 7 Hasil pengujian penggunaan informasi akuntansi, manajemen modal kerja dan umur usaha terhadap keberhasilan usaha

Tabel 7 Goodness of fit index

\begin{tabular}{|c|c|c|c|}
\hline \multicolumn{2}{|c|}{ Goodness of fit index } & \multicolumn{2}{|c|}{ Cut-off value } \\
\hline Hasil Perhitungan & & $\mathbf{K e}$ & gan \\
\hline x2(Chi-square ) & & Dihar & kecil \\
\hline 32,348 & Baik & & \\
\hline Significance Probabili & & $\geq 0$ & \\
\hline 0,120 & & & \\
\hline RMSEA & & $\leq$ & 0.08 \\
\hline 0,072 & Baik & & \\
\hline GFI & & $\geq$ & 0.90 \\
\hline 0,927 & Baik & & \\
\hline AGFI & & $\geq$ & 0.90 \\
\hline 0,912 & Baik & & \\
\hline CMIN/DF & & $\leq$ & 2.00 \\
\hline 1,852 & Baik & & \\
\hline TLI & & $\geq$ & 0.95 \\
\hline 0,958 & Baik & & \\
\hline CFI & & $\geq$ & 0.95 \\
\hline 0,956 & Baik & & \\
\hline
\end{tabular}

Tahap measurement model dilakukan dengan teknikconfirmatory 
factor analysis.Berdasarkan tabel di atas, menunjukkan bahwa seluruh parameter goodness of fit untukvariabel penggunaan informasi akuntansi, manajemen modal kerja,umur usaha dan keberhasilan usahatergolong baik, yang berarti ada kesesuaian antara model dengan data yang ada.

\section{3. Pengujian Hipotesis}

Tahapan berikutnya adalah pengujian koefisien jalur. Koefisienkoefisien jalur merepresentasikan hipotesis dalam penelitian ini. Pengujian koefisien jalur secara rinci disajikan pada tabel berikut:

Tabel 8 Hasil pengujian koefisien jalur

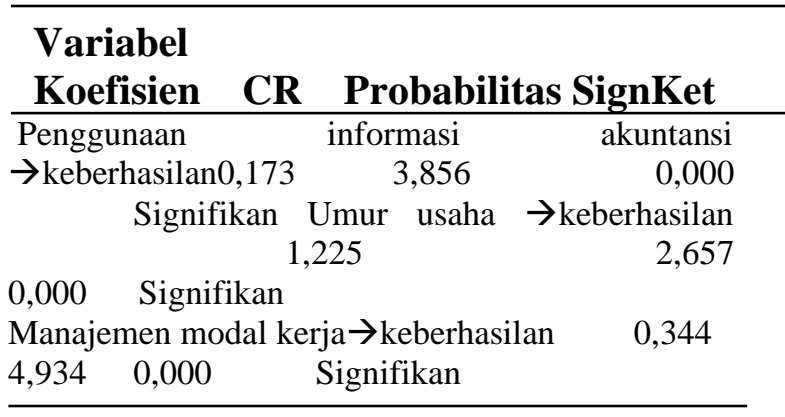

Berdasarkan

Tabel

8,dapatdiketahuibahwasemuanilai

C.R.

berada di atas 1,96 ataudengansignifikansi yang kurangdari 0,05 dengan interpretasi masing-masing koefisien jalur adalah sebagai berikut:

Penggunaan informasi akuntansi berpengaruh positif dan signifikan terhadap keberhasilan usaha yang terlihat dari koefisien jalur yang bertanda positif sebesar 0,173dengan nilai C.R. sebesar 3,856 dan diperoleh probabilitas signifikansi (p) sebesar 0,000 yang lebih kecil dari tingkat signifikansi yang ditentukan sebesar 0,05yang berarti bahwa hipotesis pertama diterima.

Umur usaha berpengaruh positif dan signifikan terhadap keberhasilan usaha yang terlihat dari koefisien jalur yang bertanda positif sebesar 1,225dengan nilai C.R. sebesar 2,657dan diperoleh probabilitas signifikansi (p) sebesar 0,000 yang lebih kecil dari tingkat signifikansi 0,05sehinggaefeklangsungvariabelumurusa hasebagaivariabelpemoderasipenggunaanin formasiakuntansiterhadapkeberhasilanusah a yang ditunjukkandengannilaikoefisiensebesar 1,398 sehinggahipotesiskeduaditerima.

Manajemen modal kerjaberpengaruh positif dan signifikan terhadap keberhasilan usaha yang terlihat dari koefisien jalur yang bertanda positif sebesar 0,344dengan nilai C.R. sebesar 4,934dan diperoleh probabilitas signifikansi (p) sebesar 0,000 yang lebih kecil dari tingkat signifikansi yang ditentukan sebesar 0,05yang berarti bahwa hipotesis ketiga diterima.

Umur usaha berpengaruh positif dan signifikan terhadap keberhasilan usaha yang terlihat dari koefisien jalur yang bertanda positif sebesar 1,225dengan nilai C.R. sebesar 2,657 dan diperoleh probabilitas signifikansi (p) sebesar 0,000 yang lebih kecil dari tingkat signifikansi 0,05sehinggaefeklangsungvariabelumurusa hasebagaivariabelpemoderasimanajemen 
modal kerjaterhadapkeberhasilanusaha yang

ditunjukkandengannilaikoefisiensebesar 1,569 sehingga hipotesis keempat diterima.

\section{4. Pembahasan Hasil Penelitian}

Hipotesis pertama menyatakan bahwa penggunaan informasi akuntansi berpengaruh positif terhadap keberhasilan usaha. Hal ini dikarenakan informasi akuntansi membantu pelaku UMKM untuk dapatmengumpulkan informasi finansial dan non finansial dengan lebih akurat dalam rangka pembuatan keputusan jangka pendek maupun pengambilan keputusan jangka panjang sehingga mengakibatkan peningkatan efisiensi dan laba usaha. Hasil penelitian ini sesuai dengan penelitian yang dilakukan oleh Indriani (2010), Nnena (2012), Smirat (2013), Arlianto (2014) dan Rini (2016) sehingga hipotesis pertama diterima.

Umur usaha sebagai variabel pemoderasi pengaruh penggunaan informasi akuntansi terhadap keberhasilan usaha memiliki pengaruh positifdansignifikan. Hal ini dikarenakan seiring bertambahnya umur usaha, para pelaku UMKM juga akan menjadi semakin peka mengenai informasi apa saja yang mereka perlukan dalam pengelolaan usahanya (Megantoro, 2015), terutama informasi yang berkaitan dengan pengambilan keputusan finansial untuk kegiatan operasional sehari-hari sehingga UMKM dapat semakin meningkatkan proses bisnisnya untuk mendukung keberhasilan usahanya.

Hipotesis ketiga menyatakan bahwa manajemen modal kerjaberpengaruh positif terhadap keberhasilan usaha. Hal ini sesuai dengan teori yang dikemukakan oleh Andreas (2011) bahwa kelemahan usaha kecil dan menengah adalah kurangnya dana untuk memenuhi pengeluaran mereka dalam beberapa bulan ke depan serta belum adanya pemisahan keuangan usaha dan keuangan rumah tangganya sehingga hal ini mempengaruhi pengambilan keputusan sehari-hari yang dalam jangka panjang akan mempengaruhi keberhasilan usaha. Hasil penelitian ini sesuai dengan penelitian yang dilakukan oleh Indriyatni (2013)

Umur usaha sebagai variabel pemoderasi pengaruh manajemen modal kerja terhadap keberhasilan usaha memiliki pengaruh positif dan signifikan. Hal ini dikarenakan semakin lama UMKM beroperasi, akan meningkatkan keterampilan manajerial terutama dalam memetakan kecukupan modal kerja yang diperlukan. Hal ini berdampak terhadap proses pengambilan keputusan yang lebih baik yang akan menuntun mereka pada peningkatan keberhasilan usaha. 


\section{KESIMPULAN}

\section{1. Kesimpulan}

1. Umur UMKM terbesar yang menjadi sampel di dalam penelitian ini berkisar antara 3 tahun sampai dengan 5 tahun sebanyak 74 UMKM atau sebesar 37\% serta UMKM yg berumur 5 -10 tahun sebanyak 64 UMKM atau sebesar 32\% dari total sampel sehingga diasumsikan mereka sudah menggunakan informasi akuntansi secara matang.

2. Berdasarkanhasil pengujian hipotesis melalui pengujian koefisien jalur dengan program AMOS v.23, dapat diperoleh kesimpulanbahwa penggunaan informasi akuntansi dan manajemen modal kerja berpengaruh positif terhadap keberhasilan UMKM. Umur usaha sebagai variabel pemoderasi juga berpengaruh secara positif dan signifikan terhadap keberhasilan UMKM. Hasil penelitian ini mendukung hampir semua penelitian yang telah dilakukan sebelumnya.

\section{2. Saran}

Saran yang dapat kami sampaikan untuk dijadikan sebagai bahan pengembangan bagi penelitian selanjutnya antara lainsebagai berikut:

1. Memperluas sampel penelitian dengan caramemasukkan semua jenis industri kreatif untuk mendapatkan hasil penelitian yang lebih baik.
2. Menambahkan variabel karakteristik pelaku UMKM untuk melihat pengaruhnya terhadap keberhasilan usaha

3. Menambahkan indikator keberhasilan usaha dari sisi finansial.

\section{DAFTAR PUSTAKA}

Andreas. 2011. Manajemen Keuangan UKM. Yogyakarta: Graha Ilmu.

Arlianto, Tenny. 2014. Pengaruh Penggunaan Informasi Akuntansi terhadap Keberhasilan UMKM (Studi Kasus pada Industri Konveksi Desa Padurenan Kecamatan Gebog Kabupaten Kudus). Universitas Kristen Satya Wacana Salatiga

Bosma, Niels. 2011. The Global Entrepreneurship Monitor (GEM) and Its Impact on Entrepreneurship Research. Boston: now Publisher Incorporation. ISBN: 978-160198-634-4

Brown, Lisanne, Anne LaFond and Kate Macintyre. 2011. Measuring Capacity Building, Carolina Population Center. Chapel Hill: University of North Carolina

Ermaliana. 2013. Implementasi Pencatatan Keuangan oleh Pengusaha Mikro Kecil di Kecamatan Ciputat. Jurnal Liquidity Vol 2 No 1 Januari-Juni

Ghozali Imam. 2011. Aplikasi Analisis Multivariate dengan Program SPSS. Edisi ke-5. Semarang : Universitas Diponegoro. 
Hidayati, E.P. dan Soesatyo, Y.2016.Pengaruh Modal Kerja dan Strategi Pemasaran terhadap Keberhasilan Usaha Kerajinan Manik-Manik Kaca Desa Plumbon Gambang Kecamatan Gudo Kabupaten Jombang.Universitas Negeri Surabaya.

Indriani. 2010. Pengaruh Karakteristik Penggunaan Informasi Akuntansi terhadap Keberhasilan Usaha pada Hotelhotel Berbintang di Wilayah Surakarta dan Daerah Istimewa Yogyakarta (DIY). Universitas Gadjah Mada Yogyakarta

Indriyatni, Lies.2013. Analisis Faktor yang Berpengaruh Terhadap Keberhasilan Usaha Mikro dan Kecil. Jurnal STIE Semarang, Vol. 5, No. 1.

Junaidi. 2017. Kualitas Sumberdaya Manusia dan Sifat Kewirausahaan Pelaku Industri Kreatif Usaha Mikro Kecil dan Menengah di Kota Jambi. Jurnal Paradigma Ekonomika Vol. 12. No. 2

Kasmir. 2016. Pengantar Manajemen Keuangan. Jakarta: Prenada Media.

Lindrayanti. 2013. Sikap Kewirausahaan dalam Hubungannya dengan Keberhasilan Usaha. Jakarta: PT Raja Grafindo

Megantoro, Dwi. 2015. Pengaruh Keterampilan, Pengalaman, Kemampuan Sumber Daya Manusia terhadap Usaha Kecil Menengah (Studi Kasus di Panjangrejo, Srihardono, Pundong, Bantul Yogyakarta). Universitas Pembangunan Nasional (UPN) Veteran Yogyakarta
Nnena, O. 2012. The Use Accounting Information as an Aid to Management in Decision Making. British Journal of Science. May 2012 Vol 5

Purwanti, Endang. 2013. Pengaruh Karakteristik Wirausaha, Modal Usaha, Strategi Pemasaran terhadap Perkembangan UMKM di Desa Dayaan dan Kalilondo Salatiga. Jurnal Ilmiah Among Makarti Vol 5 No 2.

Rochmana. Risiko Pembiayaan dan Kaitannya dengan Profitabilitas UMKM. Jakarta: PT. Raja Grafindo Persada.2011

Saefulah, Asep. Buletin APBN edisi 14 vol 1 Juli 2016. Jakarta: Pusat Kajian AnggaranBadan Keahlian DPR RI. 2016.

Smirat, Belal Yousef. 2013. The Use of Accounting Information by Small and Medium Enterprises in South District of Jordan ( An empirical study). Research Journal of Finance and Accounting Vol.4, No.6, 2013

Sugianto. 2017. Pengaruh Pendidikan, Pengalaman Usaha, dan Jenis Usaha Terhadap Penggunaan Informasi Akuntansi pada Usaha Kecil dan Menengah yang Ada di Kecamatan Tanjungpinang Timur, Kota Tanjungpinang. Universitas Maritim Raja Ali Haji Tanjungpinang 